\title{
Polymorphisms in alcohol-metabolizing enzymes and esophageal carcinoma susceptibility: a Dutch Caucasian case-control study
}

\author{
Polat Dura ${ }^{1}$, Tineke Berkers ${ }^{1}$, Elke $M$ van Veen ${ }^{1}$, Jody Salomon ${ }^{1}$, Rene HM te Morsche ${ }^{1}$, Hennie MJ Roelofs ${ }^{1}$, \\ Jon O Kristinsson ${ }^{1}$, Theo Wobbes ${ }^{2}$, Ben JM Witteman ${ }^{3}$, Adriaan CITL Tan ${ }^{4}$, Joost PH Drenth ${ }^{1}$ \\ and Wilbert HM Peters ${ }^{1}$
}

Esophageal cancer (EC), mainly consisting of squamous cell carcinoma (ESCC) in the Eastern world and adenocarcinoma (EAC) in the Western world, is strongly associated with dietary factors such as alcohol use. We aimed to clarify the modifying role in EC etiology in Caucasians of functional genotypes in alcohol-metabolizing enzymes. In all, 351 Caucasian patients with EC and 430 matched controls were included and polymorphisms in CYP2E1, ADH and near ALDH2 genes were determined. In contrast to the results on ESCC in mainly Asian studies, we found that functional genotypes of alcohol-metabolizing enzymes were not significantly associated with EAC or ESCC in an European population.

Journal of Human Genetics (2013) 58, 742-748; doi:10.1038/jhg.2013.95; published online 19 September 2013

Keywords: acetaldehyde dehydrogenase; alcohol dehydrogenase; cytochrome P450 2E1; detoxification; esophageal adenocarcinoma; esophageal squamous cell carcinoma; genetic polymorphism

\section{INTRODUCTION}

Esophageal cancer (EC) is a gravely lethal malignancy with poor 5 -year survival rates. EC can be subdivided into esophageal adenocarcinoma (EAC), more prevalent in the Western world with gastroesophageal reflux disease (GERD) and obesity as main risk factors. Esophageal squamous cell carcinoma (ESCC) is more prominent in Asia, predisposed by the use of tobacco and alcohol (ethanol) and local dietary habits. ${ }^{1}$ So tactics in averting contact with environmental and dietary factors such as alcohol intake are crucial in esophageal carcinogenesis.

Ethanol, although classified by WHO-IARC as a Group-1 carcinogen, in its pure form is less toxic than its principal metabolite acetaldehyde (AA), which is a carcinogen and partly responsible for the cancer risk. $^{2}$ Acetaldehyde is also detectable in tobacco smoke. ${ }^{3}$ The key enzymes for the oxidation of ethanol and its metabolite acetaldehyde are the phase I biotransformation enzymes cytochrome P450 2E1 (CYP2E1), alcohol dehydrogenase (ADH) and acetaldehyde dehydrogenase (ALDH). The activity of these enzymes influences AA levels. ${ }^{4}$ The primarily hepatic CYP2E1 isozyme is induced by ethanol and is also expressed in the esophagus. ${ }^{5}$ Of the ADH enzymes classes $1,3,4$ and 7, which are expressed in the esophageal epithelium, ${ }^{6,7}$ $\mathrm{ADH}$ class 1 is the most relevant as subclasses 3 and 4 have a low affinity for ethanol. ${ }^{4}$ Within the ALDH superfamily, the ALDH2 isozyme is most relevant, as it is involved in the oxidation of AA. ${ }^{4}$ ALDH2 primarily is a liver enzyme, although it is also expressed in esophageal mucosa where it is involved in the first pass metabolism of alcohol. $^{8}$

Functional polymorphisms in the genes of alcohol-metabolizing enzymes may cause alterations in the phenotypes. These polymorphisms can therefore act as a proxy for the exposure to environmental toxins such as alcohol and its main metabolite acetaldehyde.

Previously, a large Asian meta-analysis showed single-nucleotide polymorphisms (SNPs) in $A D H$ genes to be associated with an increased risk of cancer of the upper-aerodigestive tract (UADT). ${ }^{9}$ Furthermore, a Japanese genome-wide association study (GWAS) reported $A D H 1 B$ and $A L D H 2$ polymorphisms to be associated with an increased ESCC risk. ${ }^{10}$ Many case-control studies originate from the Eastern continent, so the correlation between polymorphisms in alcohol-metabolizing enzymes and modulation of ESCC risk is well established in Asian countries. ${ }^{11,12}$ In sharp contrast, at present only an American and a French case-control study examined the roles of $A D H 1 C$ and CYP2E1 genotypes in EAC ${ }^{13}$ and UADT cancer risk, ${ }^{14}$ respectively. However, the number of patients included in these studies were small; $n=137^{13}$ and $n=158^{14}$ for combined EC and UADT cases. So there is a literary gap concerning the role of functional polymorphisms in alcohol-metabolizing

${ }^{1}$ Department of Gastroenterology, Radboud University Nijmegen Medical Center, Nijmegen, The Netherlands; ${ }^{2}$ Department of Surgery, Radboud University Nijmegen Medical Center, Nijmegen, The Netherlands; ${ }^{3}$ Department of Gastroenterology, Hospital Gelderse Vallei, Ede, The Netherlands and ${ }^{4}$ Department of Gastroenterology, Canisius-Wilhelmina Hospital, Nijmegen, The Netherlands

Correspondence: Dr P Dura, Department of Gastroenterology 455, Radboud University Nijmegen Medical Center, PO Box 9101 , Nijmegen, 6500 HB, The Netherlands. E-mail: p.dura@mdl.umcn.nl

Received 5 April 2013; revised 30 July 2013; accepted 13 August 2013; published online 19 September 2013 
enzymes in Western EAC as well as ESCC cases. Consequently, we hypothesized that variant genotypes of CYP2E1, ADH1B, ADH1C, $A D H 7$ and $A L D H 2$ might alter EAC and ESCC risk in a Dutch Caucasian population. To prove our hypothesis we conducted a case-control study, including 351 patients with EAC or ESCC of Dutch Caucasian descent and 430 age-, sex- and race-matched controls.

\section{MATERIALS AND METHODS}

Patients and controls

The study was approved by the Medical Ethical Review Committee, region Arnhem-Nijmegen (CMO approval no. 2002/114) and written informed consent was received from all participants. Blood or tissue samples from 351 Caucasian patients with EC were collected in the period October 2002 to June 2012 at four different hospitals, all located within $30 \mathrm{~km}$ distance in the SouthEast area of the Netherlands. ${ }^{15}$ Patients were included in the order of entry to the hospital. Only patients with a diagnosis of esophageal carcinoma, as confirmed by a pathologist, were included in the study. As a source of DNA, in 92 cases, tissue biopsies of normal esophagus or stomach from patients were collected after surgery, whereas in 259 cases EDTA blood was collected. Blood and tissue samples were frozen at -20 and $-80^{\circ} \mathrm{C}$, respectively. DNA isolation was performed by usage of the High Pure PCR Template Preparation Kit (Roche, Mannheim, Germany) according to the instructions of the manufacturer. Post-extraction DNA was stored at $4{ }^{\circ} \mathrm{C}$. Healthy controls $(n=430)$, matched for age, sex and Caucasian race were recruited from the same geographical area of The Netherlands, after advertisement in local papers as described earlier. ${ }^{15}$

\section{Genotyping}

The extracted DNA was used for SNP detection of $A D H 1 B$ c.143A>G (rs1229984; Arg48His), $A D H 1 B$ c.1108C $>T$ (rs2066702; Arg370Cys), $A D H 1 C$ c.815G > A (rs1693482; Arg272Gln), ADH1C c.1048A > G (rs698; Ile350Val), ADH7 c.275G >C (rs1573496; Gly92Ala), CYP2E1 c.-1295G>C (rs3813867), CYP2E1 c.-1055 C>T (rs2031920) and near ALDH (rs4767364) by means of real-time PCR (rtPCR) techniques. A specific set of primers, which flank the region of the SNP, was used to amplify the DNA. In the TaqMan assay, two probes, labeled with a fluorophore at the $5^{\prime}$-end and a quencher at the $3^{\prime}$-end of the probe, were added to the PCR mixture. The PCR primers and TaqMan probes were designed by Beacon Designer (PREMIER Biosoft International, Palo Alto, CA, USA) and synthesized by Isogen Life Science (De Meern, the Netherlands). The sequences of the primers and probes, as well as the annealing temperatures and $\mathrm{MgCl}_{2}$ concentrations, are given in Table 1 . The gene expression was measured using the CFX96 Real-Time PCR Detection System (Bio-Rad Laboratories, Hercules, CA, USA).

\section{ADLH2 mutation analysis}

The ALDH2 gene consists of 13 exons. A specific set of primers, flanking the coding region, was designed for each exon, by using Primer3 software (Whitehead Institute for Biomedical Research, Cambridge, UK). A PCR followed by melting curve analysis was performed for each exon using the Bio-Rad CFX96 Real-Time PCR Detection System. The PCR also contained

Table 1 Sequences of primers and probes and annealing temperatures for the investigated SNPs in the ADH, CYP2E1 and (near) ALDH genes

\begin{tabular}{|c|c|c|c|}
\hline SNP & Primer/probe & Sequence & Annealing temperature $/\left(\mathrm{MgCl}_{2}\right)$ \\
\hline$A D H 1 B$ & Primer forward & 5'-AACAGCTTCTCTTTATTCTGTAGATGG-3' & $67^{\circ} \mathrm{C} / 6 \mathrm{~mm}$ \\
\hline \multirow[t]{3}{*}{ p.Arg48His } & Primer reverse & 5'-CTCATTGCCTTGGTTTCCTTATCC-3' & \\
\hline & Probe most common allele & 5'-(FAM)CTGTAGGAATCTGTCACACAGATGACCACGT(BHQ1)-3' & \\
\hline & Probe variant allele & 5'-(HEX)CTGTAGGAATCTGTCGCACAGATGACCACGT(BHQ1)-3' & \\
\hline \multirow[t]{4}{*}{ ADH1B p.Arg370Cys } & Primer forward & 5'-TTAACACAATGTCTCTTCTTTCC-3' & $54^{\circ} \mathrm{C} / 3 \mathrm{~mm}$ \\
\hline & Primer reverse & 5'-GGGTAGAGGAGGCTGAAG-3' & \\
\hline & Probe most common allele & 5'-(FAM)ATTGCAGTATCCGTACCGTCCTGAC(BHQ1)-3' & \\
\hline & Probe variant allele & 5'-(HEX)ATTGCAGTATCTGTACCGTCCTGAC(BHQ1)-3' & \\
\hline$A D H 1 C$ & Primer forward & 5'-AAATGACTGATGGAGGTGTGG-3' & $65^{\circ} \mathrm{C} / 6 \mathrm{~mm}$ \\
\hline \multirow[t]{3}{*}{ p.Arg272GIn } & Primer reverse & 5'-CAACCTGGAGGATGCATTTAG-3' & \\
\hline & Probe most common allele & 5'-(FAM)TGAAGTCATCGGTCGGCTTGACACCA(BHQ1)-3' & \\
\hline & Probe variant allele & 5'-(HEX)TGAAGTCATCGGTCAGCTTGACACCA(BHQ1)-3' & \\
\hline \multirow[t]{4}{*}{ ADH1C p.lle350Val } & Primer forward & 5'-CTGACTTTATGGCTAAGAAG-3' & $61^{\circ} \mathrm{C} / 5 \mathrm{~mm}$ \\
\hline & Primer reverse & 5'-AGATTGAACTGGCAATGG-3' & \\
\hline & Probe most common allele & 5'-(FAM)ATGCATTAATAACAAATATTTTACCTTTTGAAAA(BHQ1)-3' & \\
\hline & Probe variant allele & 5'-(HEX)ATGCATTAATAACAAATGTTTTACCTTTTGAAAA(BHQ1)-3' & \\
\hline$A D H 7$ & Primer forward & 5'-GTCCAAGTTTCCAGTGATTGTG-3' & $58.3^{\circ} \mathrm{C} / 3 \mathrm{~mm}$ \\
\hline \multirow[t]{3}{*}{ p.Gly92Ala } & Primer reverse & 5'-GTTTGACACCTGCATATACCTG-3' & \\
\hline & Probe most common allele & 5'-(FAM)CACTGTAGTCACTCCTTCTCCAATGCTC(BHQ1)-3' & \\
\hline & Probe variant allele & 5'-(HEX)CACTGTAGTCACTGCTTCTCCAATGCTC(BHQ1)-3' & \\
\hline rs4767364 & Primer forward & 5'-AGTTGGGATTTCGCTATGTTTC-3' & $62^{\circ} \mathrm{C} / 3 \mathrm{~mm}$ \\
\hline \multirow[t]{3}{*}{ (near $A L D H$ ) } & Primer reverse & 5'-GATGGCTTGAGGCACCTG-3' & \\
\hline & Probe most common allele & 5'-(FAM)TAACACTGGGGTACGTATACTCCACAGGT(BHQ1)-3' & \\
\hline & Probe variant allele & 5'-(HEX)TAACACTGGGGTACATATACTCCACAGGT(BHQ1)-3' & \\
\hline \multirow[t]{4}{*}{ CYP2E1-1295 } & Primer forward & 5'- ACTGGAAAGGAAAGAGAGGA-3' & $59^{\circ} \mathrm{C} / 2.5 \mathrm{~mm}$ \\
\hline & Primer reverse & 5'- AGTCATTGGTTGTGCTGC-3' & \\
\hline & Probe most common allele & 5'-(FAM)CTAACACTGCACCTCTCCTGAACC(BHQ1)-3' & \\
\hline & Probe variant allele & 5'-(HEX)CTAACACTGCAGCTCTCCTGAACC(BHQ1)-3' & \\
\hline \multirow[t]{4}{*}{ CYP2E1-1055 } & Primer forward & 5'- CATCATATTTTCTATTATACATAAAG-3' & $54^{\circ} \mathrm{C} / 4 \mathrm{~mm}$ \\
\hline & Primer reverse & 5'- GGTAGTCCATAGGTATTTTG-3' & \\
\hline & Probe most common allele & 5'-(FAM)TGTTAATATAAAAGTACAAAATTGCAACCT(BHQ1)-3' & \\
\hline & Probe variant allele & 5'-(HEX)TGTTAATATAAAAGTATAAAATTGCAACCT(BHQ1)-3' & \\
\hline
\end{tabular}

Abbreviation: SNP, single-nucleotide polymorphism. 
EvaGreen (Biotium, Hayward, CA, USA), a dye staining double-stranded DNA. The annealing temperature varied between the exons. The melt curves were analyzed using Bio-Rad Precision Melt Analysis software (Bio-Rad Laboratories). The PCR products with an abnormal melt curve and some normal PCR products were isolated after electrophoresis with the Qiaex II Gel Extraction Kit (Qiagen, Venlo, the Netherlands) and were sequenced. The outcome of the DNA sequencing was analyzed using ChromasPro, Technelysium.

\section{Statistical analyses}

The independent sample $t$-test was applied for the differences in continuos variables between characteristics of patients and controls. The chi-square test was used for analyzing nominal variables of patient characteristics and to test for differences of frequencies in predicted enzyme activity genotypes between two groups. Except for $A D H 1 C$, the most common genotype was set as reference. Odds ratios (OR) with 95\% confidence interval (95\% CI) were calculated. Stratified analyses were performed according to tumor histology. All $P$-values were two-sided and a probability level of $P<0.05$ was considered to be significant. All analyses were performed with the software SPSS for Windows, version 16.0 (SPSS Inc., Chicago, IL, USA).

Haplotypes were generated using the PLEM program. ${ }^{16}$ The most common haplotype was taken as reference in the comparison between cases and controls. Only participants with complete genotypes were included in the haplotype analyses. Haploview was used to evaluate the degree of linkage between the $A D H$ polymorphisms. ${ }^{17}$

\section{RESULTS}

Table 2 displays the characteristics of patients and controls. A total of 351 patients with EC, 260 with EAC and 85 with ESCC and 430 healthy controls were included. For six patients, the exact tumor type was not mentioned in the pathology reports. Controls were matched against the whole EC group for ethnicity, age and sex. The female sex was more present in patients with ESCC in comparison to patients with EAC $(P<0.001)$, and in comparison to controls $(P=0.003)$. Otherwise, no significant difference was found between the reported demographics of patients with EAC or ESSC, and controls.

Polymorphisms in the following alcohol-metabolizing enzymes were chosen on the basis of functionality and relevance as reported in earlier EC studies. As $\mathrm{ADH} 1 \mathrm{~B}$ and $\mathrm{ADH} 1 \mathrm{C}$ are the most important $\mathrm{ADH}$ enzymes involved in the oxidation of alcohol in the esophageal epithelium, the most common functional polymorphisms ADH1B p.Arg48His, ADH1B p.Arg370Cys, ADH1C p.Arg272Gln and ADH1C p.Ile350Val were selected for genotyping. The $A D H 1 C^{\star} 1$ allele was defined as the $272 \mathrm{Arg} 350 \mathrm{Il}$ variant, whereas the $A D H 1 C^{\star} 2$ allele is

Table 2 Characteristics of patients with esophageal cancer and controls

\begin{tabular}{lcccc}
\hline & \multicolumn{4}{c}{ All EC } \\
Characteristics & ESCC & EAC & patients & Controls \\
\hline $\begin{array}{l}\text { Number (\% of total) } \\
\text { Age (years; }\end{array}$ & $65^{\mathrm{a}}(24.2 \%)$ & $260^{\mathrm{a}}(74.1 \%)$ & $351^{\mathrm{a}}(100 \%)$ & 430 \\
mean \pm s.d.) & & & & \\
& & & & \\
Gender & & & & \\
$\quad$ Male & $56(65.9 \%)$ & $221(85.0 \%)$ & $282(80.3 \%)$ & $346(80.5 \%)$ \\
Female & $28(32.9 \%)$ & $39(15.0 \%)$ & $68(19.4 \%)$ & $84(19.5 \%)$ \\
\hline
\end{tabular}

Abbreviations: EAC, esophageal adenocarcinoma; EC, esophageal cancer; ESCC, esophageal squamous cell carcinoma.

${ }^{a}$ Note that for six patients the exact tumor type was not mentioned in the pathology report, whereas for one ESCC patient the gender is unknown. the $272 \mathrm{Gln} 350 \mathrm{Val}$ arrangement. ${ }^{18} \mathrm{ADH} 7$ is also expressed in the esophagus and has a vital role in the first pass metabolism of ethanol, ${ }^{7}$ and the allelic variant encoded by the ADH7 p.Gly92Ala polymorphism was selected for genotyping. The CYP2E1 c.-1295G >C (rs3813867) and c.-1055 C>T (rs2031920) genetic polymorphisms are known to increase the enzyme activity ${ }^{19}$ and in vitro expression. ${ }^{20}$ Both polymorphisms are highly linked, leading to either the most common $\mathrm{c} 1$, or the variant $\mathrm{c} 2$ allele. ${ }^{20}$ Consequently, genotypes can be classified as $c 1 / c 1, c 1 / c 2$ and $c 2 / c 2$.

The functional polymorphism ALDH2 p.Glu487Lys leads to the inactive allelic variant $A L D H 2^{\star} 2$ (487Lys), which is incapable of oxidizing acetaldehyde. ${ }^{4}$ However, this $A L D H 2^{\star} 2$ variant, although common in Asia, is rare in Caucasians. ${ }^{21}$ Therefore, we also performed mutation analyses of the coding sequences of the $A L D H 2$ gene to investigate whether other unknown polymorphism do exist in our Dutch Caucasian population.

Recently, a GWAS reported the 12q24 variant rs4767364, near the $A L D H$ gene, being directly correlated to fluctuations in breath and blood concentrations of alcohol and it significantly increased ESSC risk. $^{22}$ Consequently, we involved this SNP in our current study.

All polymorphisms were distributed according to the HardyWeinberg equilibrium. The genotype frequencies are depicted in Table 3. The distribution of the CYP2E1, ADH1B, ADH1C, ADH7 or near $A L D H$ rs4767364 genotypes were not significantly different between patients with EAC or ESSC and controls. The $A D H 1 B^{*} 3$ allele and the $A D H 1 B^{\star} 2^{\star} 2$ genotype did not occur in our study population. Furthermore, homozygosity for ADH7 92Ala was not found in patients with ESCC.

ADLH2 mutation analysis revealed no polymorphisms in the exons and splice sites of the $A L D H 2$ gene in our study population. The $A D H$ haplotype with the variant $\mathrm{ADH} 7$ 92Ala showed a tendency to decrease EAC risk (OR 0.65; 95\% CI 0.42-1.02). No haplotype significantly modified EAC or ESCC risk (Table 4).

Table 5 shows the results of earlier published case-control studies on alcohol-metabolizing enzymes associated with EC risk. Most studies originated from Asia, and thus ESCC was the predominant histological subtype. Four studies included patients without histological specification, however, all studies were from Asia, making ESCC the most probable subtype. Only Terry et al. ${ }^{13}$ reported on EAC risk.

Figure 1 shows the linkage disequilibrium (LD) patterns of $\mathrm{ADH} 1 \mathrm{~B}$ p.Arg48His, ADH1C p.Arg272Gln, ADH1C p.Ile350Val and ADH7 p.Gly92Ala. A nearly total linkage disequilibrium (LD) exists between both $A D H 1 C$ polymorphisms and a complete $\mathrm{LD}$ was found between both the $A D H 1 C$ and the $A D H 7$ polymorphisms. The ADH1B p.Arg48His had low LD values with the three other $A D H$ polymorphisms.

\section{DISCUSSION}

This study aimed to clarify the role of altered activity genotypes of alcohol-metabolizing enzymes in EC susceptibility in Caucasians. We did not detect significant associations between variant genotypes of CYP2E1, ADH1B and ADH1C, ADH7 or near ALDH (rs4767364) and EAC or ESSC risk in a Dutch population. Moreover, mutation analysis revealed no polymorphisms in the $A L D H 2$ gene in our study population. Our results are in contrast to many reports on EC from Asian countries, where polymorphisms in alcohol-metabolizing enzymes have a modulating role in cancer risk (Table 5). Strong associations in European populations between the $A D H 1 B, A D H 1 C$ and $A D H 7$ polymorphisms and the risk of UADT squamous cell carcinomas have also been appreciated by a large European GWAS and the subgroup analyses demonstrated the associations were 
Table 3 Genotype distribution in alcohol-metabolizing enzymes and corresponding odds ratios and confidence intervals for patients with ESCC or EAC, compared with controls

\begin{tabular}{|c|c|c|c|c|c|c|}
\hline Gene class & Genotypes & $\begin{array}{c}E S C C \\
\mathrm{n}=85(\%)\end{array}$ & OR $(95 \% \mathrm{Cl})$ & $\begin{array}{c}E A C \\
\mathrm{n}=260(\%)\end{array}$ & OR $(95 \% \mathrm{Cl})$ & $\begin{array}{c}\text { Controls } \\
n=430(\%)\end{array}$ \\
\hline \multirow[t]{3}{*}{$A D H 1 B$} & $* 1 /{ }^{*} 1$ & $83(97.6 \%)$ & Ref & 242 (93.1\%) & Ref & 406 (94.4\%) \\
\hline & $* 1 / * 2$ & 2 (2.4\%) & $0.43(0.10-1.84)$ & $18(6.9 \%)$ & $1.31(0.69-2.48)$ & $23(5.3 \%)$ \\
\hline & *2/*2 & 0 & - & 0 & - & 0 \\
\hline \multirow[t]{3}{*}{$A D H 1 C$} & Arg272Arg & 32 (37.6\%) & Ref & 99 (38.1\%) & Ref & $160(37.2 \%)$ \\
\hline & Arg272GIn & $36(42.4 \%)$ & $0.91(0.54-1.54)$ & $112(43.1 \%)$ & $0.92(0.65-1.29)$ & 197 (45.8\%) \\
\hline & GIn272GIn & $17(20.0 \%)$ & $1.18(0.62-2.26)$ & 49 (18.8\%) & $1.10(0.71-1.71)$ & 72 (16.7\%) \\
\hline \multirow[t]{3}{*}{$A D H 1 C$} & Ile350lle & 31 (36.5\%) & Ref & $98(37.7 \%)$ & Ref & $161(37.4 \%)$ \\
\hline & Ile350Val & $37(43.5 \%)$ & $0.98(0.58-1.65)$ & $114(43.8 \%)$ & $0.96(0.68-1.34)$ & $196(45.6 \%)$ \\
\hline & Val350Val & $17(20.0 \%)$ & $1.23(0.64-2.36)$ & 48 (18.5\%) & $1.10(0.70-1.71)$ & 72 (16.7\%) \\
\hline \multirow[t]{3}{*}{$A D H 7$} & Gly92Gly & $71(83.5 \%)$ & Ref & 221 (85.0\%) & Ref & 342 (79.5\%) \\
\hline & Gly92Ala & $14(16.5 \%)$ & $0.85(0.46-1.59)$ & 37 (14.2\%) & $0.73(0.47-1.11)$ & 79 (18.4\%) \\
\hline & Ala92Ala & 0 & - & $2(0.8 \%)$ & $0.39(0.08-1.84)$ & $8(1.9 \%)$ \\
\hline rs4767364 & $\mathrm{G} / \mathrm{G}$ & $39(45.9 \%)$ & Ref & $138(53.1 \%)$ & Ref & 207 ( $48.1 \%)$ \\
\hline \multirow[t]{2}{*}{ (near $A L D H$ ) } & $\mathrm{G} / \mathrm{A}$ & $38(44.7 \%)$ & $1.06(0.65-1.72)$ & 102 (39.2\%) & $0.80(0.58-1.11)$ & 191 (44.4\%) \\
\hline & $\mathrm{A} / \mathrm{A}$ & $8(9.4 \%)$ & $1.37(0.59-3.20)$ & $20(7.7 \%)$ & $0.97(0.53-1.77)$ & $31(7.2 \%)$ \\
\hline \multirow[t]{3}{*}{ CYP2E1 } & $\mathrm{c} 1 / \mathrm{c} 1$ & 79 (92.9\%) & Ref & 241 (92.7\%) & Ref & $398(92.6 \%)$ \\
\hline & $\mathrm{c} 1 / \mathrm{c} 2$ & $5(5.9 \%)$ & $0.84(0.32-2.23)$ & $16(6.2 \%)$ & $0.88(0.47-1.65)$ & $30(7.0 \%)$ \\
\hline & $\mathrm{c} 2 / \mathrm{c} 2$ & 0 & - & $1(0.4 \%)$ & $1.65(0.10-26.5)$ & $1(0.2 \%)$ \\
\hline
\end{tabular}

Abbreviations: $\mathrm{Cl}$, confidence interval; EAC, esophageal adenocarcinoma; ESCC, esophageal squamous cell carcinoma; Ref, reference; OR, odds ratio.

Table $4 \mathrm{ADH}$ haplotypes with corresponding odds ratios and confidence intervals for patients with ESCC or EAC compared with controls

\begin{tabular}{|c|c|c|c|c|c|}
\hline 0000 & 84 (49.4\%) & Ref & $262(50.4 \%)$ & Ref & 425 (49.4\%) \\
\hline 1000 & $13(7.6 \%)$ & $0.93(0.50-1.71)$ & $28(5.4 \%)$ & $0.65(0.42-1.02)$ & 71 (8.3\%) \\
\hline 0001 & 2 (1.2\%) & $0.67(0.15-2.98)$ & $12(2.3 \%)$ & $1.32(0.61-2.85)$ & $15(1.7 \%)$ \\
\hline 1110 & $1(0.6 \%)$ & $0.32(0.04-2.40)$ & 7 (1.3\%) & $0.72(0.30-1.77)$ & $16(1.9 \%)$ \\
\hline 0100 & $1(0.6 \%)$ & - & $1(0.2 \%)$ & - & 0 \\
\hline 1100 & 0 & - & $1(0.2 \%)$ & - & 0 \\
\hline 0101 & 0 & - & $1(0.2 \%)$ & - & 0 \\
\hline
\end{tabular}

Abbreviations: $\mathrm{Cl}$, confidence interval; EAC, esophageal adenocarcinoma; ESCC, esophageal squamous cell carcinoma; Ref, reference; OR, odds ratio.

aln the order of ADH7 Ala92Gly, ADH1C Ile350Val, ADH1C Arg272GIn, ADH1B Arg48His.

consistent regarding the anatomical site of esophagus. ${ }^{22,23}$ However, a major limitation of these studies is the lack of stratified analyses according to histology, as the GWAS solely included SCC type esophageal tumors. At present, one case-control study investigated the association between $\mathrm{ADH}$ and EAC. ${ }^{13}$ However, their Western study population was small $(n=114)$, patients with gastric cardia carcinomas were also included and only associations with $A D H 1 C$ were examined. So a large case-control study emphasizing EAC risk was still lacking.

We found the $A D H 1 B^{\star} 3$ allele to be absent in our Caucasian population, which is in accordance to the literature, as it is reported to be an African-specific allele. ${ }^{24}$ The distribution of the $A D H 1 B^{*} 1^{*} 2$ genotype is in agreement with the frequency reported in Europeans. ${ }^{25}$ Although we found no significant association between the $A D H 1 B$ genotypes and EC etiology in our European population, the $A D H 1 B^{\star} 2$ allele was found to be protective for ESCC in most Asian studies, except in those of Yang et al. ${ }^{26}$ and Ding et al. ${ }^{27}$ This association is most likely due to alcohol avoidance, ${ }^{28-30}$ as an increased flushing response has been associated with the $A D H 1 B^{\star} 2$ allele. $^{31}$ This flushing response is due to the combination of $A D H 1 B^{\star} 2$ and $A L D H 2^{*} 2$ alleles. The latter allele is predominant in $A s i a n s^{32}$ and correlates with increased acetaldehyde blood levels after alcohol consumption. ${ }^{33}$ The $A L D H 2^{\star} 2$ allele is not present in our Caucasian study population, we analyzed 781 Dutch Caucasians, both patients and controls, and this may also explain the absence of an $A D H 1 B^{\star} 2$ association with EC in our study. In Asian populations, the $A D H 1 B$ gene is known to act synergistically with $A L D H 2 .{ }^{34}$ Furthermore, nearly all studies described a significantly increased ESCC risk of heterozygous $A L D H 2$ genotypes. The absence of a role for $A L D H 2$ in EC etiology in our Dutch population may also be explained by the extremely high prevalence of the $A D H 1 B^{\star} 1$ allele, associated with a low conversion rate of ethanol to acetaldehyde. ${ }^{25}$

Furthermore, the combined variant genotypes of the $A D H 1 B$ and $A D H 1 C$, when set off against the wild-type genotypes, had no synergistic effects in increasing EAC risk. Terry et al. ${ }^{13}$ reported that the $A D H 1 C^{\star} 1^{\star 2}$ and $A D H 1 C^{*} 2^{*} 2$ genotypes had a tendency to 
Table 5 Results of this study in comparison to earlier case-control studies on polymorphisms in alcohol-metabolizing enzymes and esophageal cancer risk

\begin{tabular}{|c|c|c|c|c|c|c|}
\hline Case-control studies (year) & OR $(95 \% \mathrm{Cl})$ & OR $(95 \% \mathrm{Cl})$ & OR $(95 \% \mathrm{Cl})$ & OR $(95 \% \mathrm{Cl})$ & OR $(95 \% \mathrm{Cl})$ & OR $(95 \% \mathrm{Cl})$ \\
\hline Patients - controls & $A D H 1 B^{*} 1 / * 2$ & $A D H 1 B^{*} 2 /{ }^{*} 2$ & $A D H 1 C^{*} 1 / * 2$ & $A D H 1 C^{*} 2{ }^{*} 2$ & $A L D H 2 * 1 / * 2$ & $A L D H 2 * 2 / * 2$ \\
\hline $\begin{array}{l}\text { Dura (present study) } \\
\text { (the Netherlands, } 2012 \\
260 \text { EAC-430 }\end{array}$ & $1.31(0.69-2.48)$ & Not present & $\begin{array}{l}\text { I350V: } 0.96(0.68-1.34) \\
\text { R272Q: } 0.92(0.65-1.29)\end{array}$ & $\begin{array}{l}\text { V350V: } 1.10(0.70-1.71) \\
\text { Q272Q: } 1.10(0.71-1.71)\end{array}$ & NA & NA \\
\hline $\begin{array}{l}\text { Dura (present study) } \\
\text { (the Netherlands, 2012) } \\
85 \text { ESCC }-430\end{array}$ & $0.43(0.10-1.84)$ & Not present & $\begin{array}{l}\text { I350V: } 0.98(0.58-1.65) \\
\text { R272Q: } 0.91(0.54-1.54)\end{array}$ & $\begin{array}{l}\text { V350V: } 1.23(0.64-2.36) \\
\text { Q272Q: } 1.18(0.62-2.26)\end{array}$ & NA & NA \\
\hline $\begin{array}{l}\text { Bye et al. }{ }^{43} \\
\text { (Black South Africans, 2011) } \\
342 \text { ESCC-461 }\end{array}$ & NA & NA & NA & NA & $1.03(0.77-1.38)$ & $0.84(0.45-1.55)$ \\
\hline $\begin{array}{l}\text { Wang et al. }{ }^{44} \text { (China, 2011) } \\
81 \text { ESCC (female)-162 }\end{array}$ & $0.58(0.26-1.29)$ & $0.48(0.21-1.07)$ & NA & NA & $3.24(1.45-5.36)$ & $0.65(0.22-2.18)$ \\
\hline $\begin{array}{l}\text { Cui et al. }{ }^{10 \text { a }} \text { (Japan, 2009) } \\
1067 \text { ESCC-2763 }\end{array}$ & $0.29(0.22-0.37)$ & $0.24(0.19-0.31)$ & NA & NA & $3.48(2.99-4.06)$ & $0.47(0.28-0.78)$ \\
\hline $\begin{array}{l}\text { Akbari et al. }{ }^{45} \text { (Iran, 2009) } \\
746 \text { ESCC-1373 }\end{array}$ & $0.83(0.69-1.01)$ & $0.49(0.30-0.80)$ & NA & NA & NA & NA \\
\hline $\begin{array}{l}\text { Oze et al. }{ }^{46} \text { (Japan, 2009) } \\
265 \text { EC-530 }\end{array}$ & NA & NA & NA & NA & $5.55(3.56-8.65)$ & $0.71(0.09-5.61)$ \\
\hline $\begin{array}{l}\text { Ding et al. }{ }^{27} \text { (China, 2009) } \\
221 \text { EC-191 }\end{array}$ & $1.86(0.77-4.47)$ & $2.42(1.02-5.77)$ & NA & NA & $1.71(1.10-2.66)$ & $4.84(2.25-10.61)$ \\
\hline $\begin{array}{l}\text { Lee et al. }{ }^{47} \text { (Taiwain, 2008) } \\
406 \text { ESCC }-656\end{array}$ & $0.21(0.14-0.32)$ & $0.16(0.11-0.24)$ & NA & NA & $1.99(1.50-2.64)$ & $0.63(0.33-1.20)$ \\
\hline $\begin{array}{l}\text { Li et al. }{ }^{36} \\
\text { (Mixed South Africans, 2008) } \\
238 \text { ESCC-268 }\end{array}$ & NA & NA & $1.37(0.90-2.09)$ & $1.91(1.23-2.97)$ & $1.24(0.62-2.46)$ & $2.73(0.70-10.69)$ \\
\hline $\begin{array}{l}\text { Guo et al. }{ }^{48} \text { (China, 2008) } \\
80 \text { ESCC }-480\end{array}$ & $0.21(0.10-0.44)$ & $0.19(0.09-0.38)$ & NA & NA & $2.89(1.11-5.64)$ & NA \\
\hline $\begin{array}{l}\text { Yang et al. }{ }^{49} \text { (China, 2007) } \\
183 \text { ESCC/8 EAC-198 }\end{array}$ & $0.70(0.38-1.31)$ & $0.52(0.28-0.96)$ & NA & NA & $1.67(1.02-2.72)$ & $0.26(0.06-1.09)$ \\
\hline $\begin{array}{l}\text { Terry et al. }{ }^{13 b} \text { (USA, 2007) } \\
114 \text { EAC-160 }\end{array}$ & NA & NA & $0.63(0.37-1.09)$ & $0.52(0.25-1.05)$ & NA & NA \\
\hline $\begin{array}{l}\text { Chen et al. }{ }^{50} \text { (Taiwan, 2006) } \\
330 \text { ESCC-592 }\end{array}$ & $0.22(0.14-0.33)$ & $0.18(0.12-0.27)$ & NA & NA & $2.84(2.11-3.81)$ & $0.78(0.38-1.62)$ \\
\hline $\begin{array}{l}\text { Hashibe et al. }{ }^{35} \\
\text { (Eastern Europe, 2006) } \\
176 \text { ESSC-1083 }\end{array}$ & NA & NA & $\begin{array}{l}\text { I350V: } 1.61(1.07-2.43) \\
\text { R272Q: } 1.62(1.07-2.44)\end{array}$ & $\begin{array}{l}\text { V350V: } 1.74(1.02-2.98) \\
\text { Q272Q:2.03 (1.18-3.47) }\end{array}$ & NA & NA \\
\hline $\begin{array}{l}\text { Yokoyama et al. }{ }^{51} \text { (Japan, 2006) } \\
52 \text { ESCC (females) - } 412\end{array}$ & $0.64(0.23-1.79)$ & $0.48(0.18-1.31)$ & NA & NA & $1.18(0.65-2.15)$ & $1.63(0.52-5.09)$ \\
\hline $\begin{array}{l}\text { Yang et al. }{ }^{52} \text { (China, 2005) } \\
159 \mathrm{ESCC} / 6 \mathrm{EAC}-495\end{array}$ & $1.86(0.72-4.75)$ & $0.89(0.35-2.28)$ & NA & NA & $4.29(2.85-6.46)$ & $0.15(0.02-1.14)$ \\
\hline $\begin{array}{l}\text { Wu et al. }{ }^{53} \text { (Taiwan, 2005) } \\
134 \text { ESCC-237 }\end{array}$ & $0.22(0.11-0.44)$ & $0.16(0.08-0.31)$ & NA & NA & $3.54(2.19-5.70)$ & $0.94(0.25-3.52)$ \\
\hline $\begin{array}{l}\text { Yokoyama et al. }{ }^{25} \text { (Japan, 2002) } \\
234 \text { ESCC-634 }\end{array}$ & $0.20(0.12-0.34)$ & $0.17(0.11-0.29)$ & $1.93(1.23-3.03)$ & $5.90(0.53-65.4)$ & $3.66(2.62-5.10)$ & $0.25(0.06-1.07)$ \\
\hline $\begin{array}{l}\text { Boonyaphiphat et al. }{ }^{54} \\
\text { (Thailand, 2002) } \\
202 \text { ESCC-261 }\end{array}$ & $0.58(0.39-0.85)$ & $0.50(0.25-0.99)$ & NA & NA & $1.34(0.82-2.17)$ & $0.22(0.03-1.87)$ \\
\hline $\begin{array}{l}\text { Matsuo et al. }{ }^{55} \text { (Japan, 2001) } \\
102 \text { EC-241 }\end{array}$ & NA & NA & NA & NA & $2.48(1.52-4.03)$ & $0.19(0.02-1.47)$ \\
\hline $\begin{array}{l}\text { Hori et al. }{ }^{56} \text { (Japan, 1997) } \\
94 \text { ESCC-70 }\end{array}$ & $0.27(0.10-0.71)$ & $0.16(0.06-0.41)$ & NA & NA & $2.82(1.40-5.66)$ & $0.87(0.19-4.06)$ \\
\hline
\end{tabular}

Abbreviations: EAC; esophageal adenocarcinoma; EC; esophageal carcinoma; ESCC; esophageal squamous cell carcinoma; NA, not available.

For specification of the $A D H 1 B^{*} 1, A D H 1 B^{*} 2, A D H 1 C^{*} 1, A D H 1 C^{*} 2, A L D H 2^{*} 1$ and $A L D H 2 * 2$ alleles, see Materials and Methods.

For specification of the $A D H 1 B^{*} 1, A D H 1 B^{*} 2, A D H 1 C^{*} 1, A D H 1 C^{*} 2, A L D H$
$A D H 2$ and $A D H 3$ were interpreted as $A D H 1 B$ and $A D H 1 C$, respectively.

The ORs were generally reported with the high activity genotypes $A D H 1 B^{*} 1{ }^{*} 1, A D H 1 C^{*} 1{ }^{*} 1$ and $A L D H^{*} 1{ }^{*} 1$ as references, or re-calculated ${ }^{57}$ in this manner using absolute data in the articles.

aGWAS study design.

bIncludes gastric cardia adenocarcinomas.

decrease ESCC and EAC risk. However, the ADH1B gene was not analyzed, as $A D H 1 B$ variants are in linkage disequilibrium with $A D H 1 C$ polymorphisms. ${ }^{11}$ Yokoyama et al. ${ }^{25}$ reported the $A D H 1 C^{\star} 2$ low activity allele to increase ESCC risk and explained this association by the high degree of $\mathrm{LD}$ with the $A D H 1 B^{\star} 1$ allele, which was confirmed by Hashibe et al..$^{35}$ and Li et al. ${ }^{36}$ Our findings suggest that 


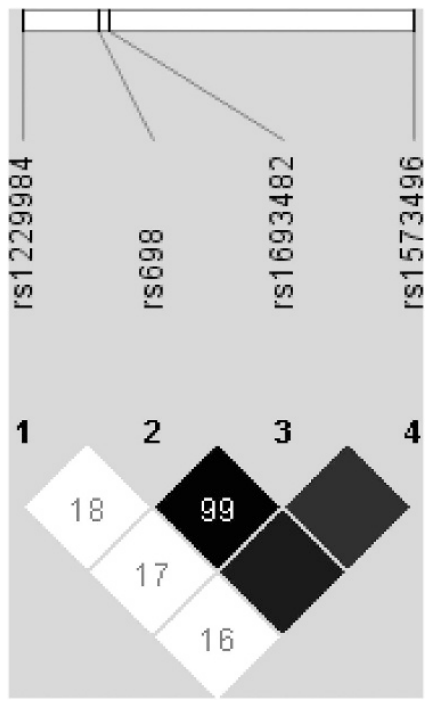

Figure 1 Linkage disequilibrium (LD) patterns between the $A D H 1 B$ Arg48His (rs1229984), ADH1C lle350Val (rs698), ADH1C Arg272GIn (rs1693482) and ADH7 Gly92Ala (rs1573496) loci. LD patterns of the single-nucleotide polymorphisms (SNPs) along the 4q22 region encompassing the $A D H$ gene, generated by Haploview. The LD between any two SNPs is shown in the cross cell. A darker color and higher number within the cell indicates a higher degree of LD. The two dark cells without numbers indicate a complete $L D$.

$A D H 1 C$ and $A D H 1 B$ are not in $\mathrm{LD}$, and no significant association between EAC or ESCC risk and $A D H 1 C$ polymorphisms exists. We also found no association with EAC or ESSC susceptibility and CYP2E1 genotypes in Caucasians. A Western study and a large Asian meta-analysis failed to confirm such an association in Brazilian and Chinese ESCC patients as well. ${ }^{37,38}$

All in all it is likely that variant genotypes of the alcoholmetabolizing enzymes ADH1B, ADH1C, ALDH2 and CYP2E1 have a role in ESCC in Asians but not in EAC or ESSC in Caucasians. Explanations may be a different ancestry gene pool, interracial differences in enzyme activity or the difference in dietary habits.

ADH7 92Ala was found to be a protective allele in upperaerodigestive cancer risk ${ }^{23}$ and also for ESCC risk. ${ }^{22}$ We now report the same effect for EAC risk, although our association did not reach statistical significance, probably due to insufficient patient numbers (OR $0.73 ; 95 \%$ CI $0.47-1.11$ ). Interestingly, the haplotype with the variant $\mathrm{ADH} 7$ 92Ala also showed the same tendency to decrease EAC risk (OR 0.65; 95\% CI 0.42-1.02).

Although altered activity genotypes can act as a proxy for the relative risk of ingested carcinogens, that is, alcohol, a limitation of our study is the absence of data on alcohol usage. This is mainly due to ethical reasons, restricting the collection of data on tobacco and alcohol use in patients newly diagnosed with a lethal disease. However, in an earlier study by us on Dutch Caucasian patients with head and neck cancer, having largely similar risk factors, it was established that at least 1-4 alcoholic beverages per day were consumed in $88 \%$ of the patients with head and neck cancer and $83 \%$ of the controls. ${ }^{39}$ This indicates that, despite of the missing data, by far most of our EC patients may have consumed alcohol and only a few may have not.

Another limitation is the small group of ESCC patients and the subsequent power of our results on ESCC. This is caused by stratifying according to histology, but was necessary, as most casecontrol studies concerning polymorphisms in alcohol-metabolizing enzymes originate from Asia and results on adenocarcinoma risk are scarce.

Although acetaldehyde induces development of adenocarcinomas in animal models, ${ }^{10}$ in humans the role of ethanol in the genesis of EAC is still under debate, as in contrast to earlier reports, ${ }^{40}$ recent studies suggest that alcohol consumption does not have a role in EAC etiology. ${ }^{41,42}$ This may largely explain why no effects of functional polymorphisms in alcohol-metabolizing enzymes were found in modulating EAC risk.

In conclusion, this study suggests that polymorphisms in alcoholmetabolizing enzymes, having a role in ESCC etiology, are not associated with EC susceptibility in an European population.

\section{CONFLICT OF INTEREST}

The authors declare no conflict of interest.

\section{ACKNOWLEDGEMENTS}

P Dura was financially supported by BBMRI-NL, a Research Infrastructure financed by the Dutch government (NWO 184.021.007; grants CP 28 and CP2011-02)

1 Hiyama, T., Yoshihara, M., Tanaka, S. \& Chayama, K. Genetic polymorphisms and esophageal cancer risk. Int. J. Cancer 121, 1643-1658 (2007).

2 Salaspuro, M. Acetaldehyde as a common denominator and cumulative carcinogen in digestive tract cancers. Scand. J. Gastroenterol. 44, 912-925 (2009).

3 Brunnemann, K. D., Cox, J. E. \& Hoffmann, D. Analysis of tobacco-specific $\mathrm{N}$-nitrosamines in indoor air. Carcinogenesis 13, 2415-2418 (1992).

4 Marichalar-Mendia, X., Rodriguez-Tojo, M. J., Acha-Sagredo, A., Rey-Barja, N. \& Aguirre-Urizar, J. M. Oral cancer and polymorphism of ethanol metabolising genes. Oral. Oncol. 46, 9-13 (2010).

5 Bergheim, I., Wolfgarten, E., Bollschweiler, E., Holscher, A. H., Bode, C. \& Parlesak, A. Cytochrome P450 levels are altered in patients with esophageal squamous-cell carcinoma. World J. Gastroenterol. 13, 997-1002 (2007).

6 Jelski, W., Kozlowski, M., Laudanski, J., Niklinski, J. \& Szmitkowski, M. Alcohol dehydrogenase isoenzymes and aldehyde dehydrogenase activity in the sera of patients with esophageal cancer. Clin. Exp. Med. 9, 131-137 (2009).

7 Birley, A. J., James, M. R., Dickson, P. A., Montgomery, G. W., Heath, A. C., Whitfield, J. B. et al. Association of the gastric alcohol dehydrogenase gene ADH7 with variation in alcohol metabolism. Hum. Mol. Genet. 17, 179-189 (2008).

8 Morita, M., Oyama, T., Kagawa, N., Nakata, S., Ono, K., Sugaya, M. et al. Expression of aldehyde dehydrogenase 2 in the normal esophageal epithelium and alcohol consumption in patients with esophageal cancer. Front. Biosci. 10, 2319-2324 (2005).

9 Guo, H., Zhang, G. \& Mai, R. Alcohol dehydrogenase-1B Arg47His polymorphism and upper aerodigestive tract cancer risk: a meta-analysis including 24,252 subjects. Alcohol. Clin. Exp. Res. 36, 272-278 (2012).

10 Cui, R., Kamatani, Y., Takahashi, A., Usami, M., Hosono, N., Kawaguchi, T. et al. Functional variants in $\mathrm{ADH} 1 \mathrm{~B}$ and $\mathrm{ALDH} 2$ coupled with alcohol and smoking synergistically enhance esophageal cancer risk. Gastroenterology 137, 1768-1775 (2009).

$11 \mathrm{Li}$, Q. D., Li, H. Wang, M. S, Diao, T, Y, Zhou, Z, Y, Fang, Q. X et al Multisusceptibility genes associated with the risk of the development stages of esophageal squamous cell cancer in Feicheng County. BMC. Gastroenterol. 11, 74 (2011).

12 Zhang, G. H., Mai, R. Q. \& Huang, B. Meta-analysis of ADH1B and ALDH2 polymorphisms and esophageal cancer risk in China. World J. Gastroenterol. 16, 6020-6025 (2010).

13 Terry, M. B., Gammon, M. D., Zhang, F. F., Vaughan, T. L., Chow, W. H., Risch, H. A. et al. Alcohol dehydrogenase 3 and risk of esophageal and gastric adenocarcinomas. Cancer Causes Control 18, 1039-1046 (2007)

14 Lucas, D., Menez, C., Floch, F., Gourlaouen, Y., Sparfel, O., Joannet, I. et al. Cytochromes P4502E1 and P4501A1 genotypes and susceptibility to cirrhosis or upper aerodigestive tract cancer in alcoholic caucasians. Alcohol Clin. Exp. Res. 20, 1033-1037 (1996).

15 Kristinsson, J. O., van Westerveld, P., te Morsche, R. H. M., Roelofs, H. M. J., Wobbes, T., Witteman, B. J. et al. Cyclooxygenase-2 polymorphisms and the risk of esophageal adeno- or squamous cell carcinoma. World J. Gastroenterol. 15, 3493-3497 (2009).

$16 \mathrm{Li}$, Z., Zhang, Z., He, Z., Tang, W., Li, T., Zeng, Z. et al. A partition-ligationcombination-subdivision EM algorithm for haplotype inference with multiallelic markers: update of the SHEsis (http://analysis.bio-x.cn). Cell Res. 19, 519-523 (2009).

17 Barrett, J. C., Fry, B., Maller, J. \& Daly, M. J. Haploview: analysis and visualization of LD and haplotype maps. Bioinformatics 21, 263-265 (2005).

18 Benzon Larsen, S., Vogel, U., Christensen, J., Hansen, R. D., Wallin, H., Overvad, K. et al. Interaction between ADH1C $\operatorname{Arg}(272) \mathrm{Gln}$ and alcohol intake in relation to breast 
cancer risk suggests that ethanol is the causal factor in alcohol related breast cancer Cancer Lett. 295, 191-197 (2010).

19 Huang, Y. S., Chern, H. D., Su, W. J., Wu, J. C., Chang, S. C., Chiang, C. H. et al. Cytochrome P450 2E1 genotype and the susceptibility to antituberculosis druginduced hepatitis. Hepatology 37, 924-930 (2003).

20 Hayashi, S., Watanabe, J. \& Kawajiri, K. Genetic polymorphisms in the 5'-flanking region change transcriptional regulation of the human cytochrome P450IIE1 gene. J. Biochem. 110, 559-565 (1991).

21 Goedde, H. W., Agarwal, D. P., Fritze, G., Meier-Tackmann, D., Singh, S., Beckmann, G. et al. Distribution of $\mathrm{ADH} 2$ and $\mathrm{ALDH} 2$ genotypes in different populations. Hum. Genet. 88, 344-346 (1992)

22 McKay, J. D., Truong, T., Gaborieau, V., Chabrier, A., Chuang, S. C., Byrnes, G. et al. A genome-wide association study of upper aerodigestive tract cancers conducted within the INHANCE consortium. PLoS Genet. 7, e1001333 (2011).

23 Hashibe, M., McKay, J. D., Curado, M. P., Oliveira, J. C., Koifman, S., Koifman, R. et al. Multiple ADH genes are associated with upper aerodigestive cancers. Nat. Genet. 40, 707-709 (2008)

24 Osier, M. V., Lu, R. B., Pakstis, A. J., Kidd, J. R., Huang, S. Y. \& Kidd, K. K. Possible epistatic role of ADH7 in the protection against alcoholism. Am. J. Med. Genet. B Neuropsychiatr. Genet. 126B, 19-22 (2004).

25 Yokoyama, A., Kato, H., Yokoyama, T., Tsujinaka, T., Muto, M., Omori, T. et al. Genetic polymorphisms of alcohol and aldehyde dehydrogenases and glutathione S-transferase M1 and drinking, smoking, and diet in Japanese men with esophageal squamous cell carcinoma. Carcinogenesis 23, 1851-1859 (2002).

26 Yang, C. X., Matsuo, K., Ito, H., Hirose, K., Wakai, K., Saito, T. et al. Esophageal cance risk by ALDH2 and ADH2 polymorphisms and alcohol consumption: exploration of gene-environment and gene-gene interactions. Asian Pac. J. Cancer Prev. 6, 256-262 (2005).

27 Ding, J. H., Li, S. P., Cao, H. X., Wu, J. Z., Gao, C. M., Su, P. et al. Polymorphisms of alcohol dehydrogenase-2 and aldehyde dehydrogenase-2 and esophageal cancer risk in Southeast Chinese males. World. J. Gastroenterol. 15, 2395-2400 (2009).

28 Borras, E., Coutelle, C., Rosell, A., Fernández-Muixi, F., Broch, M., Crosas, B. et al. Genetic polymorphism of alcohol dehydrogenase in europeans: the ADH2*2 allele decreases the risk for alcoholism and is associated with $A D H 3 * 1$. Hepatology 31 , 984-989 (2000)

29 Neumark, Y. D., Friedlander, Y., Thomasson, H. R. \& Li, T. K. Association of the $\mathrm{ADH} 2 * 2$ allele with reduced ethanol consumption in Jewish men in Israel: a pilot study. J. Stud. Alcohol 59, 133-139 (1998).

30 Whitfield, J. B., Nightingale, B. N., Bucholz, K. K., Madden, P. A., Heath, A. C. \& Martin, N. G. ADH genotypes and alcohol use and dependence in Europeans. Alcohol Clin. Exp. Res. 22, 1463-1469 (1998).

31 Macgregor, S., Lind, P. A., Bucholz, K. K., Hansell, N. K., Madden, P. A., Richter, M. $M$. et al. Associations of ADH and ALDH2 gene variation with self report alcohol reactions, consumption and dependence: an integrated analysis. Hum. Mol. Genet. 18 580-593 (2009).

32 Yokoyama, T., Yokoyama, A., Kato, H., Tsujinaka, T., Muto, M., Omori, T. et al. Alcohol flushing, alcohol and aldehyde dehydrogenase genotypes, and risk for esophageal squamous cell carcinoma in Japanese men. Cancer Epidemiol. Biomarkers Prev. 12, 1227-1233 (2003).

33 Mizoi, Y., Yamamoto, K., Ueno, Y., Fukunaga, T. \& Harada, S. Involvement of genetic polymorphism of alcohol and aldehyde dehydrogenases in individual variation of alcohol metabolism. Alcohol Alcohol 29, 707-710 (1994).

34 Yokoyama, A., Muramatsu, T., Omori, T., Matsushita, S., Yoshimizu, H., Higuchi, S. et al. Alcohol and aldehyde dehydrogenase gene polymorphisms influence susceptibility to esophageal cancer in Japanese alcoholics. Alcohol Clin. Exp. Res. 23, 1705-1710 (1999).

35 Hashibe, M., Boffetta, P., Zaridze, D., Shangina, O., Szeszenia-Dabrowska, N., Mates D. et al. Evidence for an important role of alcohol- and aldehyde-metabolizing genes in cancers of the upper aerodigestive tract. Cancer Epidemiol. Biomarkers Prev 15, 696-703 (2006)

36 Li, D. P., Dandara, C., Walther, G. \& Parker, M. I. Genetic polymorphisms of alcohol metabolising enzymes: their role in susceptibility to oesophageal cancer. Clin. Chem Lab. Med. 46, 323-328 (2008).

37 Rossini, A., Rapozo, D. C., Soares Lima, S. C., Guimarães, D. P., Ferreira, M. A., Teixeira, R. et al. Polymorphisms of GSTP1 and GSTT1, but not of CYP2A6, CYP2E1 or GSTM1, modify the risk for esophageal cancer in a western population. Carcinogenesis 28, 2537-2542 (2007)
38 Yang, C. X., Matsuo, K., Wang, Z. M. \& Tajima, K. Phase I/II enzyme gene polymorphisms and esophageal cancer risk: a meta-analysis of the literature. World J. Gastroenterol. 11, 2531-2538 (2005).

39 Lacko, M., Voogd, A. C., Roelofs, H. M. J., te Morsche, R. H. M., Ophuis, M. B., Peters W. H. M. et al. (2012)Combined effect of genetic polymorphisms in phase I and II biotransformation enzymes on head and neck cancer risk. Head Neck 37, 858-867 2013.

40 World Cancer Research Fund/American Institute for Cancer Research Food, nutrition, physical activity and the prevention of cancer: a global perspective 162-164 (AICR, Washington DC, 2007).

41 Lubin, J. H., Cook, M. B., Pandeya, N., Vaughan, T. L., Abnet, C. C., Giffen, C. et al. The importance of exposure rate on odds ratios by cigarette smoking and alcoho consumption for esophageal adenocarcinoma and squamous cell carcinoma in the Barrett's Esophagus and Esophageal Adenocarcinoma Consortium. Cancer Epidemiol. 36, 306-316 (2012)

42 Tramacere, I., Pelucchi, C., Bagnardi, V., Rota, M., Scotti, L., Islami, F. et al. A metaanalysis on alcohol drinking and esophageal and gastric cardia adenocarcinoma risk. Ann. Oncol. 23, 287-297 (2012).

43 Bye, H., Prescott, N. J., Matejcic, M., Rose, E., Lewis, C. M., Parker, M. I. et al. Population-specific genetic associations with oesophageal squamous cell carcinoma in South Africa. Carcinogenesis 32, 1855-1861 (2011).

44 Wang, Y., Ji, R., Wei, X., Gu, L., Chen, L., Rong, Y. et al. Esophageal squamous cell carcinoma and ALDH2 and ADH1B polymorphisms in Chinese females. Asian Pac. J. Cancer Prev. 12, 2065-2068 (2011).

45 Akbari, M. R., Malekzadeh, R., Shakeri, R., Nasrollahzadeh, D., Foumani, M., Sun, Y. et al. Candidate gene association study of esophageal squamous cell carcinoma in a high-risk region in Iran. Cancer. Res. 69, 7994-8000 (2009).

46 Oze, I., Matsuo, K., Suzuki, T., Kawase, T., Watanabe, M., Hiraki, A. et al. Impact of multiple alcohol dehydrogenase gene polymorphisms on risk of upper aerodigestive tract cancers in a Japanese population. Cancer Epidemiol. Biomarkers Prev. 18, 3097-3102 (2009).

47 Lee, C. H., Lee, J. M., Wu, D. C., Goan, N. Y. G., Chou, S. H., Wu, I. C. et al Carcinogenetic impact of ADH1B and ALDH2 genes on squamous cell carcinoma risk of the esophagus with regard to the consumption of alcohol, tobacco and betel quid. Int. J. Cancer 122, 1347-1356 (2008).

48 Guo, Y. M., Wang, Q., Liu, Y. Z., Chen, H. M., Qi, Z. \& Guo, Q. H. Genetic polymorphisms in cytochrome P4502E1, alcohol and aldehyde dehydrogenases and the risk of esophageal squamous cell carcinoma in Gansu Chinese males. World J. Gastroenterol. 14, 1444-1449 (2008).

49 Yang, S. J., Wang, H. Y., Li, X. Q., Du, H. Z., Zheng, C. J., Chen, H. G. et al. Genetic polymorphisms of ADH2 and ALDH2 association with esophageal cancer risk in southwest China. World J. Gastroenterol. 13, 5760-5764 (2007).

50 Chen, Y. J., Chen, C., Wu, D. C., Lee, C. H., Wu, C. I., Le, J. M. et al. Interactive effects of lifetime alcohol consumption and alcohol and aldehyde dehydrogenase polymorphisms on esophageal cancer risks. Int. J. Cancer 119, 2827-2831 (2006).

51 Yokoyama, A., Kato, H., Yokoyama, T., Igaki, H., Tsujinaka, T., Muto, M. et al. Esophageal squamous cell carcinoma and aldehyde dehydrogenase-2 genotypes in Japanese females. Alcohol Clin. Exp. Res. 30, 491-500 (2006).

52 Yang, C. X., Matsuo, K., Ito, H., Hirose, K., Wakai, K., Saito, T. et al. Esophageal cancer risk by ALDH2 and ADH2 polymorphisms and alcohol consumption: exploration of gene-environment and gene-gene interactions. Asian Pac. J. Cancer Prev 6, 256-262 (2005).

53 Wu, C. F., Wu, D. C., Hsu, H. K., Kao, E. L., Lee, J. M., Lin, C. C. et al. Relationship between genetic polymorphisms of alcohol and aldehyde dehydrogenases and esophageal squamous cell carcinoma risk in males. World J. Gastroenterol. 11, 5103-5108 (2005).

54 Boonyaphiphat, P., Thongsuksai, P., Sriplung, H. \& Puttawibul, P. Lifestyle habits and genetic susceptibility and the risk of esophageal cancer in the Thai population. Cance Lett. 186, 193-199 (2002).

55 Matsuo, K., Hamajima, N., Shinoda, M., Hatooka, S., Inoue, M., Takezaki, T. et al. Gene-environment interaction between an aldehyde dehydrogenase-2 (ALDH2) polymorphism and alcohol consumption for the risk of esophageal cancer. Carcinogenesis 22, 913-916 (2001).

56 Hori, H., Kawano, T., Endo, M. \& Yuasa, Y. Genetic polymorphisms of tobacco- and alcohol-related metabolizing enzymes and human esophageal squamous cell carcinoma susceptibility. J. Clin. Gastroenterol. 25, 568-575 (1997).

57 Bland, J. M. \& Altman, D. G. Statistics notes. The odds ratio. BMJ 320, 1468 (2000). 